Jurnal Bisnis dan Manajemen, Volume 21, No. 1, March 2020, p. 27-42

\title{
PROMOTION MIX, INDIVIDUAL INTERNAL ENVIRONMENT, AND PURCHASE DECISION MAKING IN MINIMARKET
}

\author{
Apri Budianto ${ }^{1}$, Irma Darmawati Bastaman ${ }^{2}$, Ferey Herman ${ }^{3}$ \\ 1,2,3 Universitas Galuh, Indonesia
}

\begin{abstract}
This study analyzes the effect of the promotion mix and the internal environment of individuals on consumer purchasing decisions. The promotion mix has a positive relationship with purchasing decisions because consumers will be introduced to various products and influence the desire of consumers to buy these products. Meanwhile the positive relationship of an individual's internal environment with consumer purchasing decisions will, therefore, be a consideration in making decisions. The new contribution of this study concerns the relationship between the promotion mix literature and the separate internal environment of individuals regarding consumer purchasing decisions. To test the hypothesis, we use the parametric statistical analysis method through Structural Equation Modeling. We conducted this study on the perceptions of minimarket consumers in the Priangan Timur region in Indonesia, whereas many as 400 customers were selected randomly. The results of the study show that the promotion mix and the internal environment of individuals influence consumer purchasing decisions. Other results show that the promotional mix applied by minimarkets based on consumer perceptions gets an attractive category. While the individual's internal environment based on consumer perception becomes a consideration in making a decision.
\end{abstract}

Keywords: promotion mix, individual internal environment, consumer purchasing decisions, minimarket, modern retail

\section{BAURAN PROMOSI, LINGKUNGAN INTERNAL INDIVIDU DAN PENGAMBILAN KEPUTUSAN PEMBELIAN PADA MINIMARKET}

\begin{abstract}
ABSTRAK
Studi ini menganalisis pengaruh bauran promosi dan lingkungan internal individu terhadap keputusan pembelian konsumen. Bauran promosi memiliki hubungan yang positif terhadap keputusan pembelian, karena konsumen akan dikenalkan dengan berbagai produk dan mempengaruhi hasrat konsumen untuk membeli produk tersebut. Sementara itu hubungan positif lingkungan internal individu dengan keputusan pembelian konsumen, karena itu akan menjadi pertimbangan dalam pengambilan keputusan. Kontribusi baru dari studi ini, yaitu menyangkut hubungan literature bauran promosi dan lingkungan internal individu yang terpisah mengenai keputusan pembelian konsumen.. Untuk menguji hipotesis, kami menggunakan metode analisis statistika parametric melalui sebuah alat, yaitu Structural Equation Medelling. Studi ini kami lakukan terhadap persepsi konsumen minimarket pada wilayah Priangan Timur di Indonesia, dimana konsumen yang menjadi sampel adalah sebanyak 400 orang yang dipilih secara acak. Hasil studi menunjukan bahwa bauran promosi dan lingkungan internal individu berpengaruh terhadap keputusan pembelian konsumen. Hasil lainnya, menunjukan bahwa bauran promosi yang diterapkan minimarket berdasarkan persepsi konsumen memperoleh kategori menarik. Sedangkan lingkungan internal individu berdasarkan persepsi konsumen menjadi pertimbangan dalam pengembilan keputusan.
\end{abstract}

Kata-kata Kunci: bauran promosi, lingkungan internal individu, keputusan pembelian konsumen, minimarket, ritel modern

Korespondensi: Dr. Apri Budianto, M.M. Universitas Galuh. Jln. RE Martadinata, Ciamis, 46274, Jawa Barat, Indonesia. Email: apribudiantogaluh@gmail.com

Submitted: October 2019, Accepted: March 2020, Published: March 2020

ISSN: 1412 - 3681 (printed), ISSN: 2442 - 4617 (online), Website: http://journal.feb.unpad.ac.id/index.php/jbm 


\section{Jurnal Bisnis dan Manajemen, Volume 21, No. 1, March 2020, p. 27-42}

\section{INTRODUCTION}

Indonesia's economic growth and acceleration are primarily determined by the sectors that influence it, one of which is the trade sector (Fadli, 2016; Maulana \& Bowo, 2013; Wardana, 2016). Since the emergence of the modern market in Indonesia, this sector has experienced a change that is indicated by the rapid development of the modern market, where the growth of the modern market reached $31.40 \%$ (Yustika, 2007). One of the goals of Indonesia's economic development is to increase national income, which is supported by equitable distribution of population, business sectors, and regional economic improvement (Salim, 2002; Lestari \& Suhadak, 2019; Rochaida, 2016). In line with that to anticipate the demands of globalization, the government is trying to utilize business sectors that contribute greatly to state revenues (Junaidi, Sulasmiyati, \& Nurlaily, 2018; Rinaldi, Jamal, \& Seftarita, 2017; Sedyaningrum, Suhadak, \& Nuzula, 2016).

The increase in national income from the trade sector is due to a change in the holistic marketing context (Kussudyarsana, 2008; Rosyad, 2011; Hendrayati \& Syahidah, 2018). This condition is inseparable from the large role of marketing management in business (Sandy, Arifin, \& Yaningwati, 2014; Pertiwi, Yulianto, \& Sunarti, 2016; Wardi, Abror, \& Trinanda, 2018). The task of marketing management in business is to develop marketing strategies and plans, seize marketing enlightenment, connect with customers, build strong brands, form market bids, deliver value, communicate value, and create long-term growth (Kotler \& Keller, 2009). For this reason, marketing management needs to get special attention, as their role plays a role in the success of a business.

Increased public purchasing power opens up opportunities for retail businesses to reap maximum profits (Simbolon, 2011; Karwur, 2016; Anggraini., Arifin, \& Slamet, 2015). In addition, the lifestyle of the people who currently prefer the concept of self-service applied by modern retail businesses (Tumbel \& Rate, 2015; Marendra, 2018; Wandebori \& Wijaya, 2017). With the change of the trade paradigm in Indonesia, the core concepts, trends, and marketing tasks have also changed (Rusdianto, 2015; Mauna, Hufron, \& Khoirul, 2017; Wardhana, Syahputra, \& Kartawinata, 2017). The core concept of marketing is a set of concepts creating a foundation for marketing management and holistic marketing orientation (Kotler \& Keller, 2009).

In the current era of globalization, there has been very tight competition among retail businesses, even between individuals, thus demanding innovation-based competition (Arifianti \& Raharja, 2018; Kasman, Maupa, \& Jusni, 2019; Parsons \& Descatoires, 2016). In fact, with the increasingly integrated world economy, almost all companies will face nagging and demanding customers (for example, according to Porter, 2008), including the modern retail business. Such customers always demand better quality, timely supply, low prices, and 
Jurnal Bisnis dan Manajemen, Volume 21, No. 1, March 2020, p. 27-42

excellent service (Naufal \& Magnadi, 2017; Kusumowidagdo, Sachari, \& Widodo, 2012). Thus only modern retail businesses that are efficient, effective, innovative and productive will be able to survive and even win in competition. Meanwhile, those who are unable to compete will experience setbacks and even do not rule out bankruptcy (Fadilla, 2015; Hermawati, 2013; Johansson \& Kask, 2016).

The retail business in Indonesia has experienced rapid development in recent years with a variety of formats and types, especially the growth of minimarkets. This condition proves the rapid growth of business in the trade sector, as a result of the development of manufacturing businesses and open market opportunities. In addition, the role of the government in driving the development of retail business is very significant. The government plays a role in protecting the national retail business through regulations and laws. The development of retail in Indonesia is shown by the increasing number of retails with various types, such as 152 hypermarkets, 157 supermarkets, and around 7000 minimarkets (Yusuf, 2009). The most minimarket type of retail business compared to other types.

Several studies on retail business have been carried out, such as those conducted by (Kusumowidagdo et al., 2012; Hermawati, 2013; Naufal \& Magnadi, 2017), which focused on public behavior and marketing mix strategies. The study results state that there is a relationship between the promotional mix strategy on purchasing decisions and people's behavior in shopping. While not many studies have been found that are focused on the internal environment and purchasing decisions (eg, Nasikan \& Sasmito, 2013; Karimi, Holland, \& Papamichail, 2018), where the results of his study explain that an individual's internal environment can influence consumer purchasing decisions.

The new contribution of this study concerns the relationship between the promotional mix literature and the separate internal environment of individuals regarding consumer purchasing decisions. To our knowledge, this is the first study to document the relationship between the promotion mix, the internal environment of individuals, and consumer purchasing decisions. In this study, we took a sample of minimarket consumers in the Priangan Timur region. A total of 400 people were randomly selected and determined to be the sample in this study.

This paper continues as follows. In the next section, we describe our literature review and hypothesis. The third part explains the research design and sample determination. The fourth section reports the results of our empirical analysis, and the fifth section summarizes the conclusions drawn from the results of this study. 
Jurnal Bisnis dan Manajemen, Volume 21, No. 1, March 2020, p. 27-42

\section{LITERATURE REVIEW}

\section{Relationship of Promotion Mix with Consumer Purchasing Decision Making Process}

The promotion mix is a promotional tool that we are familiar with that includes advertising activities, personal selling, sales promotion, public relations, word of mouth, direct marketing, and publications (Lupiyoadi \& Hamdani, 2008; Kotler \& Keller, 2009). The promotional mix is an optimal combination of various types of promotional tools and strategies or the selection of the most effective ones to increase sales (Suliyanto, 2006; Ederm, Swait \& Louviere, 2002). From a combination of various effective promotional tools and strategies, businesses hope to influence consumers' decisions to buy their products.

Before making a purchase, each consumer makes various kinds of decisions about the search, the benefits of using a variety of products and brands at any given period (Blut, Teller, \& Floh, 2018; Fadilla, 2015). Various kinds of decisions regarding life activities often have to be made by every consumer every day, not least in the effort to consume goods and services (Hermawati, 2013; Bukova, Brumercikova, Kondek, \& Groma, 2017). The purchasing decision is the choice of an action from two or more choices for a product (Sciffman \& Kanuk, 2004).

The results of the consumer decisionmaking process are post-purchase behavior consisting of purchase (trial, repeat purchase) and post-purchase evaluation (Naufal \&
Magnadi, 2017; Carpenter, 1997; Wahab, Hassan, Shahid, \& Maon, 2016). Based on this information, it is clear that the promotional mix encourages consumers to make decisions during prepurchase, purchase, and post-purchase in addition to the influences of other external and internal consumer factors.

\section{Relationship of the Individual Internal Environment with the Consumer Purchasing Decision Making Process}

The individual's internal environment is one of the factors that influence consumers' decisions to make purchases of products or services needed (Morrison, 2010). By knowing the factors driving these consumer decisions, retail businesses must adjust their products to the elements of individual internal factors such as needs, desires, and motivations, perceptions, learning, consumer personalities, consumer lifestyles, and consumer self-concepts, as well as considering external factors individuals such as culture, reference groups, social classes, opinions of someone who is trusted by consumers, and consumers' families (Nasikan \& Sasmito, 2013; Chokenukul, Sukhabot, \& Rinthaisong, 2017). This means that companies consider these two factors to adjust to the suitability of the promotional strategy that must be used in introducing their products.

After making a purchase, there are several possible consumer actions that need to be evaluated, namely not buying again, buying again repeatedly, or even inviting others to buy 
Jurnal Bisnis dan Manajemen, Volume 21, No. 1, March 2020, p. 27-42

the product (Tanner \& Tanner, 1998; Karimi, Holland, \& Papamichail, 2018). Repurchases are made by consumers if they are satisfied, and if the product's performance increases and in accordance with consumer expectations, then ultimately, consumers will have high loyalty to the product (Horovitz, 2000). By considering some of the literature, the internal environment, and the external environment have a strong relationship with the consumer purchasing decision-making process.

\section{Hypothesis Development}

In this section, we discuss the relationship between promotion mix, individual internal environment, and consumer purchasing decisions. Evidenced by the theoretical foundation and empirical analysis of the relationship between the three provides a clue why consumer purchasing decisions on a product are influenced by an effective promotional mix and the internal environment of individuals.

First, products sold by retail businesses will not find customers themselves (Cohen et al., 2018; Blut et al., 2018). Therefore, retail businesses must be able to recognize consumers, so they know what is needed by consumers. One way for retail businesses to do this is to use promotional strategies to influence consumers to buy a product (Johansson \& Kask, 2016; Griva, Bardaki, Pramatari, \& Papakiriakopoulos, 2018; Marendra, 2018). The success of promotion certainly cannot be separated from how promotion is managed strategically and carried out with the right strategy (Parsons \& Descatoires, 2016; Karwur, 2016; Hermawati, 2013). Determination of the right model and media in the promotion strategy is the most effective form of communication in the marketing of a product (Astuti, Silalahi, \& Wijaya, 2015; Azzadina, Huda, \& Sianipar, 2012). Thus, effective promotion strategies can influence purchasing decisions from consumers.

Second, there are various factors that influence why a consumer buys certain products to meet his needs. These factors include internal factors and external factors (Nasikan \& Sasmito, 2013; Oghazi, Karlsson, Hellström, \& Hjort, 2018). Internal factors are one of the important things to be the center of attention because they most likely can influence purchasing decisions (Azzadina et al., 2012; Nasikan \& Sasmito, 2013). Individual internal factors include perceptions, attitudes, lifestyle, and personality, were psychological, and sociological factors that generally determine a person's behavior (Nasikan \& Sasmito, 2013; Chokenukul et al., 2017). Some experts put forward the magnitude of the influence of the above factors on consumer behavior, social class factors, family, style, life, personality, self-ability, perception, and learning, is the attitude of consumers in making a purchase of a product (Morrison, 2010; Tanner, 1998). Thus, an individual's internal factors of a consumer will influence the purchase decision of a product. 
Jurnal Bisnis dan Manajemen, Volume 21, No. 1, March 2020, p. 27-42

To understand consumer behavior, retail businesses will be able to understand the needs and desires of consumers, which can then be used to follow up in making decisions effective marketing activities (Wahab et al., 2016; Naufal \& Magnadi, 2017). In addition, understanding consumer behavior is to find out whether there are new opportunities that come from not meeting a customer's needs (Suki, Suki, \& Azman, 2016; Wongleedee, 2015). The need to understand consumer behavior is based on factors that influence the consumer's decisionmaking process to buy a product. Therefore, the relationship between the promotion mix, the individual's internal environment, and the customer purchasing decision is illustrated in the following model.

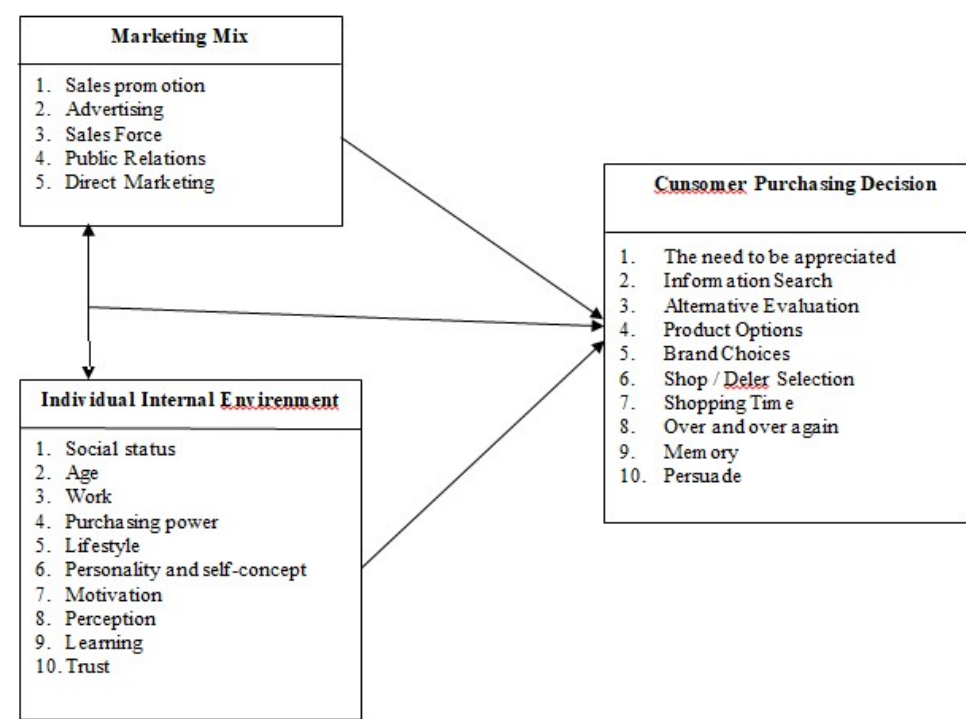

Figure 1. Research Model

Overall, all the statements above show that the implementation of an effective promotional strategy will be able to influence consumer purchasing decisions on a product, compared to the application of an ineffective promotion strategy. In addition, individual internal factors will influence consumer purchasing decisions regarding a product, because these factors determine the behavior of a consumer. Thus, the hypothesis to be tested is:

$\mathrm{H}_{1}$ : Promotional mix affects the consumer purchasing decision-making process.

$\mathrm{H}_{2}$ : The individual's internal environment influences the consumer's purchasing decision-making process.

$\mathrm{H}_{3}$ : Promotional mix and individual internal environment influence the consumer purchasing decision-making process.

\section{METHODS}

\section{Research Design and Population}

The population in this study were all minimarket consumers in the Priangan Timur area for a week. Based on the results of a week's survey of consumers who came and shopped at minimarkets throughout the Priangan Timur region, there were 88,500 people, with the following details.

Table 1. Population Design Based on Minimarket Domicile

\begin{tabular}{clccc}
\hline No. District/City & $\begin{array}{c}\text { Minimarket } \\
\text { Amount }\end{array}$ & $\begin{array}{c}\text { Average } \\
\text { Visitors }\end{array}$ & $\begin{array}{c}\text { Number } \\
\text { of } \\
\text { Visitors }\end{array}$ \\
\hline 1. & Sumedang & 30 & 500 & 15,000 \\
2. Garut & 54 & 500 & 27,000 \\
3. Tasikmalaya & 39 & 500 & 19,500 \\
4. Tasikmalaya & 13 & 500 & 6,500 \\
5. Ciamis & 32 & 500 & 16,000 \\
6. & Banjar & 500 & 4,500 \\
\hline \multicolumn{4}{c}{ Total Population } \\
\hline
\end{tabular}

Source: Research Result (2019)

Since it is not possible to take all population units by considering the ability of researchers in terms of funding, time, and other 
Jurnal Bisnis dan Manajemen, Volume 21, No. 1, March 2020, p. 27-42

facilities and supporters, it is also not possible to conduct a census. For this reason, in this study, we draw samples that can represent all population units using the Slovin formula at a significant rate of $\alpha=0.05$.

$$
\mathrm{n}=\frac{\mathrm{N}}{\mathrm{N} \cdot \alpha^{2}+1}
$$

Information $: \mathrm{n}=$ Number of Samples

$\mathrm{N}=$ Number of Population

$\alpha^{2}=$ Prescribed Precision (5\%)

So that,

$$
\mathrm{n}=\frac{88,500}{88,500(0.05)^{2}+1}=398,200 \text { persons }
$$

Rounded up to 400 persons.

In this study, we determined the respondents, which consisted of a number of minimarkets in 6 regions in the Priangan Timur region. The determination of the location of the minimarkets is proportionally determined from all regencies and cities in the Priangan Timur region, namely in the western part of 160 , the central part of 140 , and the eastern part of 100 respondents.

The determination of sample size will depend on the analytical method used. Therefore, we use the parametric statistical analysis method through SEM (Structural Equation Modeling) analysis tools. Furthermore, data analysis using SEM follows 7 stages: (1) theoretically developing the model; (2) make a path diagram that illustrates the causality relationship; (3) convert the path diagram into a measurement and structural model; (4) choose the type of matrix input and systemize the proposed model; (5) assess the identified model; (6) evaluating the Goodness-of-Fit criteria, and (7) interpretation and modification of the proposed model.

Thus the indices used to test the feasibility of the model are shown in Table 2 as follows.

Table 2. Model Conformance Index

\begin{tabular}{lc}
\hline \multicolumn{1}{c}{ Conformance Index $\chi^{\mathbf{2}}$} & Value Recommendation \\
\hline Significance Probability $\chi^{2}$ & $\geq 0.05$ \\
NFI & $>0.90$ \\
RMSEA & $\leq 0.08$ \\
\hline
\end{tabular}

\section{RESULTS AND DISCUSSION \\ Instrument Test (Validity test and reliability test)}

LISREL estimation results for each dimension we need to explain further. This explanation is needed because each variable is measured indirectly, but is formed by a number of indicators that need to be examined for their role in shaping these variables. For more details, it will be discussed in each hypothesis testing.

As a result of using SEM (Structural Equation Modeling) by using LISREL 8.7, the equivalent model in Figure 2 below is obtained. 
Jurnal Bisnis dan Manajemen, Volume 21, No. 1, March 2020, p. 27-42

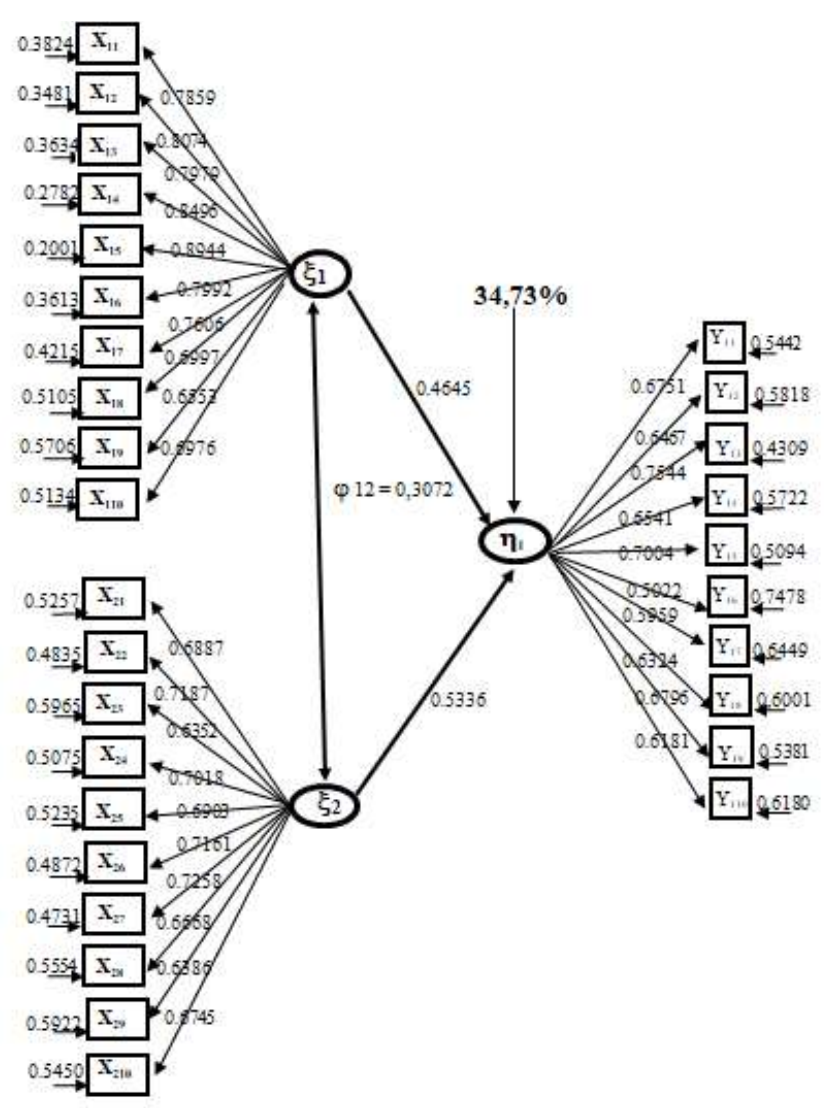

Figure 2. Structure Analysis of the Effects of $\xi_{1}$ and $\xi_{2}$ on $\eta_{1}$

Of the ten indicators that measure the promotional mix, the dimension of messageoriented advertising media is the more dominant indicator in the formation of the promotional mix variable. This is reflected in the weight factor of the dimensions of advertising media $(0.8944)$ and the message-oriented orientation in advertising (0.8496) is greater than the weight of the other 8-dimensional factors. Next, we examine whether the dimensions used to measure promotion mix variables have a high degree of conformity, so the construct reliability and variance extracted approach is used. The test results for each dimension of the promotional mix variable are described in Table 3 as follows.
Table 3. Summary of Statistical Computational Results for the Promotional Mix Measurement Model

\begin{tabular}{ccccc}
\hline Dimension & $\begin{array}{c}\text { Standardized } \\
\text { Loading }\end{array}$ & $\begin{array}{c}\text { (Standardized } \\
\text { Loading) }\end{array}$ & $\begin{array}{c}\text { t } \\
\text { Value* }\end{array}$ & $\begin{array}{c}\text { Error } \\
\text { Variance }\end{array}$ \\
\hline $\mathrm{X}_{11}$ & 0.7859 & 0.6176 & 18.5565 & 0.3824 \\
$\mathrm{X}_{12}$ & 0.8074 & 0.6519 & 19.3098 & 0.3481 \\
$\mathrm{X}_{13}$ & 0.7979 & 0.6366 & 18.9808 & 0.3634 \\
$\mathrm{X}_{14}$ & 0.8496 & 0.7218 & 20.8924 & 0.2782 \\
$\mathrm{X}_{15}$ & 0.8944 & 0.7999 & 22.7433 & 0.2001 \\
$\mathrm{X}_{16}$ & 0.7992 & 0.6387 & 19.0457 & 0.3613 \\
$\mathrm{X}_{17}$ & 0.7606 & 0.5785 & 17.7031 & 0.4215 \\
$\mathrm{X}_{18}$ & 0.6997 & 0.4895 & 15.7739 & 0.5105 \\
$\mathrm{X}_{19}$ & 0.6553 & 0.4294 & 14.4717 & 0.5706 \\
$\mathrm{X}_{110}$ & 0.6976 & 0.4866 & 15.7125 & 0.5134 \\
\hline Amount & \multicolumn{5}{|c}{} & 0.3953
\end{tabular}

Construct Reliability $=0.9386$

Variance Extracted $=0.6048$

$*_{\text {t-critical }}=1.96$

The construct reliability of the ten dimensions used to measure the promotion mix variable is still greater, and the recommended one is greater than 0.7 (Hair et al, 1998), thus it can be stated that the construction value has met the limits to be accepted. These results indicate that the indicators used in the promotional mix latent variable have a good fit. $\mathrm{t}$ values greater than 1.96 indicate that the dimensions used are significant in forming the mixing variable. Extracted variance value of 0.6048 gives a clue that $60.48 \%$ of the information contained in the 10 dimensions is represented by the promotional mix variable.

In Table 3, it can be seen that the estimated value of the direct marketing indicator parameter is 0.4294 which is the smallest loading factor value and forms an exogenous variable of the promotion mix with a reliability value $\left(r^{2}\right)$ of $42.94 \%$, meaning that the indicator can be explained in the exogenous variable of the promotional mix of $42.94 \%$. To find out the 
Jurnal Bisnis dan Manajemen, Volume 21, No. 1, March 2020, p. 27-42

most dominant sub-variables of the promotion mix variable can be seen in Table 4 .

Table 4. Calculation of Standardized Loading for Promotional Mix Variables Sub-variables

\begin{tabular}{cccc}
\hline Indicator & $\begin{array}{c}\text { Sub } \\
\text { Variable }\end{array}$ & $\begin{array}{c}\text { Standardized } \\
\text { Loading }\end{array}$ & $\begin{array}{c}\text { Standardized } \\
\text { Loading } \\
\text { Rata-Rata }\end{array}$ \\
\hline $\mathrm{X}_{11}$ & Sales & 0.7859 & \\
$\mathrm{X}_{12}$ & Promotion & 0.8074 & 0.7971 \\
$\mathrm{X}_{13}$ & & 0.7979 & \\
$\mathrm{X}_{14}$ & Advertising & 0.8496 & 0.8720 \\
$\mathrm{X}_{15}$ & & 0.8944 & \\
$\mathrm{X}_{16}$ & Sales Force & 0.7792 & 0.7792 \\
$\mathrm{X}_{17}$ & Public & 0.7606 & 0.7080 \\
$\mathrm{X}_{18}$ & Relations & 0.6997 & \\
$\mathrm{X}_{19}$ & Direct & 0.6553 & 0.6765 \\
$\mathrm{X}_{110}$ & Marketing & 0.6976 & \\
\hline
\end{tabular}

Source: Research Result (2019)

From Table 4, it can be seen that the most dominant sub-variable using LISREL is the advertising of 0.8720 , while the smallest is direct marketing. Furthermore, out of the 10 indicators that measure an individual's internal environment, the dimensions of motivation and age-oriented are more dominant indicators in the formation of individual internal environment variables. This is evidenced in the weighting factor of the motivational dimension of 0.7258 and the age-oriented factor of 0.7187 is greater than the weight of the other 8 dimensional factors.

Furthermore, testing of the dimensions used to measure individual internal environmental variables whether they have a high degree of conformity, the construct reliability, and the variance extracted approach is used. The test results for each dimension of the individual internal environment variables are described in Table 5.
Table 5. Summary of Statistical Computing

Results for Individual Internal Environment Variable Measurement Models

\begin{tabular}{ccccc}
\hline Dimension & $\begin{array}{c}\text { Standardized } \\
\text { Loading }\end{array}$ & $\begin{array}{c}\text { (Standardized }^{\text {Loading) }} \\
\text { L }\end{array}$ & t Value* & $\begin{array}{c}\text { Error } \\
\text { Variance }^{-}\end{array}$ \\
\hline $\mathrm{X}_{21}$ & 0.6887 & 0.4743 & 15.1485 & 0.5257 \\
$\mathrm{X}_{22}$ & 0.7187 & 0.5165 & 16.0955 & 0.4835 \\
$\mathrm{X}_{23}$ & 0.6352 & 0.4035 & 13.6415 & 0.5965 \\
$\mathrm{X}_{24}$ & 0.7018 & 0.4925 & 15.5168 & 0.5075 \\
$\mathrm{X}_{25}$ & 0.6903 & 0.4765 & 15.2080 & 0.5235 \\
$\mathrm{X}_{26}$ & 0.7161 & 0.5128 & 15.9646 & 0.4872 \\
$\mathrm{X}_{27}$ & 0.7258 & 0.5269 & 16.2754 & 0.4731 \\
$\mathrm{X}_{28}$ & 0.6668 & 0.4446 & 14.5337 & 0.5554 \\
$\mathrm{X}_{29}$ & 0.6386 & 0.4078 & 13.7142 & 0.5922 \\
$\mathrm{X}_{210}$ & 0.6745 & 0.4550 & 14.7316 & 0.5450 \\
Amount & & 0.4710 & & 0.5289 \\
\hline Construct Reliability $=0.8990$ & & & \\
Variance Extracted $=0.4710$ & & & \\
*t-critical $=1.96$ & & &
\end{tabular}

The construct reliability of the 10 dimensions used to measure individual internal environment variables is still greater and the recommended one is greater than 0.7 (Hair et al, 1998), thus it can be stated that the construction value has met the limits to be accepted and this shows that indicators used on latent individual internal environment variables have a good fit. The $t$ value indicates that the dimension used is significant in shaping the individual's internal environment variable ( $\mathrm{t}$ value is greater than 1.96). Extracted variance value of 0.4710 indicates that $47.10 \%$ of the information contained in ten dimensions is represented in the individual internal environment variables.

From Table 5, it can be seen that the estimated value of the occupational indicator parameters is 0.4035 which is the smallest loading factor value and forms the exogenous variable of the individual internal environment with a reliability value $\left(\mathrm{r}^{2}\right)$ of $40.35 \%$, meaning that the indicator can be explained in the exogenous variable of the individual's internal 
Jurnal Bisnis dan Manajemen, Volume 21, No. 1, March 2020, p. 27-42

environment of $40.35 \%$ The most dominant sub variable of the individual internal environment variables is motivation, while the smallest is the work.

Furthermore, of the ten indicators that measure the process of consumer purchasing decision making, alternative dimensions of evaluation and choice of physical form are more dominant indicators in the formation of a customer purchasing decision making variables. This is evidenced by the weight of alternative evaluation dimension factor of 0.7544 and oriented to the choice of the physical form of 0.7004 greater than the weight of other 8dimensional factors.

The next test, whether the dimensions used to measure the variables of the customer purchasing decision-making process, has a high degree of conformity. The construct reliability and variance extracted approach is used. The test results for each dimension of the customer purchasing decision-making process variable are shown in Table 6.

\section{Table 6. Summary of Computational Results Statistics Variable Measurement Model Customer Purchasing Decision Making Process}

\begin{tabular}{ccccc}
\hline Dimension & $\begin{array}{c}\text { Standardized } \\
\text { Loading }\end{array}$ & $\begin{array}{c}\text { (Standardized } \\
\text { Loading) }\end{array}$ & $\begin{array}{c}\mathbf{t} \\
\text { Value* }^{*}\end{array}$ & $\begin{array}{c}\text { Error } \\
\text { Variance }\end{array}$ \\
\hline $\mathrm{Y}_{11}$ & 0.6751 & 0.4558 & 14.6940 & 0.5442 \\
$\mathrm{Y}_{12}$ & 0.6467 & 0.4182 & 13.8254 & 0.5818 \\
$\mathrm{Y}_{13}$ & 0.7544 & 0.5691 & 17.2305 & 0.4309 \\
$\mathrm{Y}_{14}$ & 0.6541 & 0.4278 & 14.1831 & 0.5722 \\
$\mathrm{Y}_{15}$ & 0.7004 & 0.4906 & 15.4751 & 0.5094 \\
$\mathrm{Y}_{16}$ & 0.5022 & 0.2522 & 10.3391 & 0.7478 \\
$\mathrm{Y}_{17}$ & 0.5959 & 0.3551 & 12.6552 & 0.6449 \\
$\mathrm{Y}_{18}$ & 0.6324 & 0.3999 & 13.6038 & 0.6001 \\
$\mathrm{Y}_{19}$ & 0.6796 & 0.4619 & 14.8653 & 0.5381 \\
$\mathrm{Y}_{110}$ & 0.6181 & 0.3820 & 13.1208 & 0.6180 \\
Amount & & 0.4213 & & 0.5787
\end{tabular}

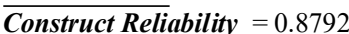

Variance Extracted $=0.4213$

*t-critical $=1.96$
The construct reliability of the ten dimensions used to measure the customer purchasing decision making process variable is still greater and the recommended one is greater than 0.7 (Hair et al, 1998), thus it can be stated that the construction value has met the limits to be accepted and matters this shows that the indicators used in the customer purchase decision-making variable have a good fit. The $t$ value indicates that the dimension used is significant in shaping the variable of the customer purchasing decision-making process $(\mathrm{t}$ value is greater than 1.96). Extracted variance value of 0.4213 indicates that $42.13 \%$ of the information in 10 dimensions is represented in the variable customer decision-making process.

From Table 6 , it can be seen that the estimated value of the minimarket parameter selection indicator is 0.2522 which is the smallest loading factor value that forms the endogenous variable of the customer's decision making process with a reliability value $\left(\mathrm{r}^{2}\right)$ of $25.22 \%$, meaning that the indicator can be explained in the endogenous variable customer decision of $25.22 \%$. The most dominant subvariable of the customer purchase decisionmaking process variable is the evaluation alternative, while the smallest one is the selection of the minimarket name.

In this study, a model is presented in Figure 2. To find out whether the model is acceptable or not, a simultaneous or overall model testing is performed using the goodness 
Jurnal Bisnis dan Manajemen, Volume 21, No. 1, March 2020, p. 27-42

of fit. Based on the test results, the following results are obtained.

Table 7. The goodness of Fit (GoF) Test Results

\begin{tabular}{cccc}
\hline No. & GoF Size & Model & Estimation \\
& & Criteria & \\
\hline 1 & $\chi^{2}$ (Chi-square) & P-Value $>$ & 2929.58 \\
& $d f=735$ & 0.05 & with P-Value $=$ \\
& & & 0.0000 \\
2 & NFI & $>0.90$ & 0.9114 \\
3 & RMSEA & $<0.05$ & 0.045 \\
\hline
\end{tabular}

Source: Research Result (2019)

Table 7 shows that the overall model test results have met the size of the model suitability. Thus, the structural equation model presented in Figure 2 can be said that the model is appropriate to explain this whole study. From the calculation results obtained $\chi^{2}$ value of 3939.58 with $\mathrm{p}$-value $=0.0000$. This value indicates that the $\chi^{2}$ test is significant. Based on the above criteria, the model obtained does not meet the ideal criteria, but if the value of $\chi^{2}$ is less than 2 times, the degree of freedom can still be accepted. For the model studied, the magnitude of the degree of freedom is 735 , so the model obtained can still be declared good because the value of $\chi^{2}$ and this model is less than 2 times the degree of freedom.

Judging from the second criterion, the NFI (Normed Fit Index) value of this model is 0.9114 within acceptable limits, so this model can be stated as good. Furthermore, it can be seen from the RSMEA for the model studied that it is 0.045 , so it can be said that the model is acceptable because it is still in the acceptable range, which is between 0.05-0.08.
Of the three criteria that can be met by this study model, it is concluded that the model can be used to explain the relationship of each variable studied. This means that the model obtained can explain the relationship and influence of the promotional mix and the individual's internal environment on the customer's purchasing decision-making process. Thus the simultaneous hypothesis stating that there is a significant influence between the promotional mix and the individual's internal environment on the customer's buying decisionmaking process is acceptable.

Table 8. Hypothesis Test Partial Effect of Promotion Mix and Individual Internal Environment Against the Customer Purchasing Decision Making Process

\begin{tabular}{clcccc}
\hline No & Hypothesis & $\begin{array}{c}\text { Path } \\
\text { Coefficient }\end{array}$ & tcount & table & Result \\
\hline 1 & $\begin{array}{l}\text { Promotion } \\
\text { Mix }\end{array}$ & 0.4645 & 10.4704 & 1.96 & $\mathrm{Sig}$ \\
2 & $\begin{array}{l}\text { Individual } \\
\text { Internal } \\
\text { Environment }\end{array}$ & 0.5336 & 12.5825 & 1.96 & $\mathrm{Sig}$ \\
\hline
\end{tabular}
Source: Research Result (2019)

Based on table 8 , it can be seen that partially the promotion mix and the internal environment of an individual have an influence on the customer purchasing decision-making process. These results can be seen in statistical conclusions or decision criteria where the hypothesis $\mathrm{H}_{0}$ is rejected. The first hypothesis is obtained a coefficient value of 0.4645 with a $\mathrm{t}_{\text {count }}$ of $10.4704>\mathrm{t}_{\text {table }}$ of 1.96 , it can be concluded statistically that the promotional mix variable influences the customer purchasing decision-making process. Furthermore, the 
Jurnal Bisnis dan Manajemen, Volume 21, No. 1, March 2020, p. 27-42

second hypothesis is obtained a coefficient value of 0.5336 with a $t_{\text {count }}$ of $12.5825>t_{\text {table }}$ of 1.96 , it can be concluded that the individual's internal environment variables influence the customer purchasing decision-making process.

Exogenous variable test results, namely the promotion mix and the internal environment of individuals with endogenous variables of the customer decision-making process using the LISREL program, obtained a significant coefficient value. Furthermore, in more detail explained the total direct and indirect effects of each latent variable promotional mix and the individual's internal environment on the customer's decision-making process. The calculation results can be seen in Table 9 as follows.

Table 9. Results of the Influence of Promotion Mix and Individual Internal Environment Against the Customer Purchasing Decision Making Process

\begin{tabular}{|c|c|c|c|c|c|}
\hline \multirow[b]{2}{*}{ Variable } & \multicolumn{5}{|c|}{ Big Influence } \\
\hline & Formula & Direct & & $\begin{array}{l}\text { Indirect } \\
\text { Information }\end{array}$ & Total \\
\hline \multirow[t]{2}{*}{ Promotion Mix } & $\gamma^{2} \eta_{1} \xi_{1}$ & $21.58 \%$ & & & $29.19 \%$ \\
\hline & $\begin{array}{c}\gamma \eta_{1} \xi_{1} \times \phi \xi_{1} \xi_{2} \\
\times \gamma \eta_{1} \xi_{2}\end{array}$ & & $7.61 \%$ & $\begin{array}{c}\text { Through } \\
\xi_{2}\end{array}$ & \\
\hline Individual Internal & $\gamma^{2} \eta_{1} \xi_{2}$ & $28.47 \%$ & & & $36.08 \%$ \\
\hline Environment & $\begin{array}{c}\gamma \eta_{1} \xi_{2} \times \phi_{1} \xi_{2} \\
x \gamma \eta_{1} \xi_{1}\end{array}$ & & $7.61 \%$ & $\begin{array}{c}\text { Through } \\
\xi_{1}\end{array}$ & \\
\hline \multicolumn{5}{|c|}{ Simultaneous Influence $\xi_{1} \xi_{2}$ to $\eta_{1}\left(R^{2} \eta_{1} \xi_{1} \xi_{2}\right)$} & $65.27 \%$ \\
\hline \multicolumn{5}{|c|}{ The Influence of External Variables $\left(R^{2} \eta_{1} \varepsilon\right)$} & $34.73 \%$ \\
\hline \multicolumn{5}{|c|}{ Total Influence } & $100 \%$ \\
\hline
\end{tabular}

Source: Research Result (2019)

From Table 9, it can be seen that the total effect of the promotional mix and the internal environment of an individual on the customer purchasing decision-making process is $65.27 \%$. These results indicate that variations in changes in the purchasing decision-making process that are considered by customers when buying a product are simultaneously influenced by the promotional mix and the individual's internal environment by $65.27 \%$ and the remaining $34.73 \%$ is influenced by other variables not examined.

The magnitude of the influence of the promotional mix on the customer purchasing decision-making process is $29.19 \%$, which comes from direct and indirect influence. Meanwhile the magnitude of the influence of an individual's internal environment on the customer's buying decision-making process is $36.08 \%$, which comes from its direct and indirect influence.

Various institutions have explained that the promotion mix is the right mechanism to influence consumer purchasing decisions (eg, Sandy et al., 2014; Wongleedee, 2015; Astuti et al., 2015). The assumption is that the consumer promotion mix will be introduced to quality and useful products, in addition to that with various types of consumer promotion tools will be stimulated to be interested in purchasing these products. Furthermore, the individual's internal environment is one of the factors that can influence consumer purchasing decisions, where various institutions have explained it (eg, Nasikan \& Sasmito, 2013; Karimi et al., 2018). The assumption is that various traits and characters that exist in consumers will trigger the decision of whether to buy or not.

However, from the various strands of literature that we have explained, carried out separately, and documented mixed empirical 
Jurnal Bisnis dan Manajemen, Volume 21, No. 1, March 2020, p. 27-42

evidence. Overall we find support for our main hypothesis that the promotion mix and the internal environment of individuals can influence consumer purchasing decisions. The results of our study make a contribution to the literature, where we expand two separate literature strands to date about the relationship of the promotion mix, the internal environment of individuals, and consumer purchasing decisions. For this purpose, when put together in one study without conditions of interaction, we prove that the promotional mix and the internal environment of individuals are able to influence consumer purchasing decisions. These results are consistent with the findings of other researchers (e.g., Griva et al., 2018; Karimi et al., 2018; Blut et al., 2018; Mauna et al., 2017; Nasikan \& Sasmito, 2013).

\section{CONCLUSION}

We conclude that the promotion mix and the internal environment of individuals influence consumer purchasing decisions in minimarkets in the Priangan Timur region. The promotional mix used by the minimarkets according to consumers' perceptions is in the attractive category, while the individual's internal environment according to consumers' perceptions is a consideration in decision making. Our results provide instructions for modern retail businesses to pay attention to an effective promotional mix strategy and must pay attention to the internal environment of individual consumers because it is one of the triggers for consideration in making a decision to buy a product. The results support the company's commitment to pay attention to various strategies that must be applied in promotional activities, as well as strengthen human resources related to promotional activities.

However, this study does not directly analyze the implementation of various strategies implemented by other types of modern retail, because it is possible to obtain diverse results. Future studies can explore the promotion mix applied by other types of modern retailers, broaden the study results. Regarding the individual's internal environment and consumer purchasing decisions, the next researcher can be carried out in different countries with strong cultural differences, which will broaden the results.

\section{REFERENCES}

Anggraini., M. D., Arifin, H. R., \& Slamet, A. R. (2015). Analisis Bauran Pemasaran Eceran Terhadap Keputusan Pembelian (Studi Kasus Pada Distro Resist Wear Turen Malang). E Jurnal Riset Manajemen, xxx(xxx), 117-131. Arifianti, R., \& Raharja, S. J. (2018). Retail Mix Analysis From Consumer Perspective: Study on Three Minimarkets in Bandung City. Jurnal Pemikiran Dan Penelitian Administrasi Bisnis Dan Kewirausahaan, 3(2), 111-121.

Astuti, R., Silalahi, R. L. R., \& Wijaya, G. D. P. (2015). Marketing Strategy Based on Marketing Mix Influence on Purchasing Decisions of Malang Apples Consumers at Giant Olympic Garden Mall (MOG), Malang City, East Java Province, Indonesia. Agriculture and Agricultural Science Procedia, $\quad 3, \quad 67-71$. 
Jurnal Bisnis dan Manajemen, Volume 21, No. 1, March 2020, p. 27-42

https://doi.org/10.1016/j.aaspro.2015.01.015

Azzadina, I., Huda, A. N., \& Sianipar, C. P. M. (2012). Understanding Relationship between Personality Types, Marketing-mix Factors, and Purchasing Decisions. Procedia - Social and Behavioral Sciences, 65, 352-357. https://doi.org/10.1016/j.sbspro.2012.11.133

Blut, M., Teller, C., \& Floh, A. (2018). Testing Retail Marketing-Mix Effects on Patronage: A Meta-Analysis. Journal of Retailing, 94(2), 113-135. https://doi.org/10.1016/j.jretai.2018.03.001

Bukova, B., Brumercikova, E., Kondek, P., \& Groma, P. (2017). The Usage of Cognitive Maps in the Comparison of Marketing Mix of Railway Passenger Transport. Procedia Engineering, 187, 498-503. https://doi.org/10.1016/j.proeng.2017.04.406

Carpenter, G.S. (1997). Consumer Decisionmaking Process. Journal of Consumer Marketing, Vol. 11, No. 3, pp 33-43.

Chokenukul, P., Sukhabot, S., \& Rinthaisong, I. (2017). A causal relationship model of purchasing behavior of consumers in Thailand regarding processed fish products. Kasetsart Journal of Social Sciences, 1-7. https://doi.org/10.1016/j.kjss.2017.10.006

Cohen, D. A., Bogart, L., Castro, G., Rossi, A. D., Williamson, S., \& Han, B. (2018). Beverage marketing in retail outlets and the balance calories initiative. Preventive Medicine, 115(July), 1-7. https://doi.org/10.1016/j.ypmed.2018.07.014

Erdem, T., Swait, J., \& Louviere, J. (2002). The Impact of Brand Credibility on Consumer Price Sentivity. International Journal of Research in Marketing, 19, 1-19.

Fadilla, N. (2015). Pengaruh Strategi Diferensiasi Terhadap Keunggulan Bersaing Ritel Modern (Khusus Hypermart Mall SKA Pekanbaru). JOM FISIP, 2(2), 37-39.

Fadli, F. (2016). Adakah Pengaruh Pertumbuhan Ekonomi terhadap Pendapatan Asli Daerah? Jurnal Ilmu Ekonomi Dan Pembangunan, 16(2), $62-73$. https://doi.org/10.20961/jiep.v16i2.2312

Griva, A., Bardaki, C., Pramatari, K., \& Papakiriakopoulos, D. (2018). Retail business analytics: Customer visit segmentation using market basket data.
Expert Systems with Applications, 100, 1-16. https://doi.org/10.1016/j.eswa.2018.01.029

Hair, J.F.J., Anderson, R.E., Tatham, R.L. \& Black, W.C. (1998). Multivariate Data Analysis, 5th edition, Upper Saddle River: Prentice Hall.

Hendrayati, H., \& Syahidah, R. K. (2018). Barriers and Possibilities of Implementation of Customer Relationship Management on Small and Medium Enterprises by Womenpreneurs. Jurnal Bisnis Dan Manajemen, 19(2), 72-87.

Hermawati, A. (2013). Analisis Strategi Marketing Mix Modern Ritel Terhadap Kepuasan Minat Masyarakat dan Loyalitas Minat Masyarakat. Jurnal Manajemen Dan Akuntansi, 2(3), 66-77.

Horovitz, B. (2012). Afte rGen X, Millennials, what should next generationbe?. USA Today. Retrieved 24 November 2012.

Johansson, T., \& Kask, J. (2016). Configurations of business strategy and marketing channels for e-commerce and traditional retail formats: A Qualitative Comparison Analysis (QCA) in sporting goods retailing. Journal of Retailing and Consumer Services, 34, 1-26. https://doi.org/10.1016/j.jretconser.2016.07.0 09

Junaidi, S. K., Sulasmiyati, S., \& Nurlaily, F. (2018). Pengaruh Pendapatan Nasional , Inflasi Dan Nilai Tukar Yuan Terhadap Impor Indonesia dari China Periode 20102017. Jurnal Administrasi Bisnis, 60(2), 111-118.

Karimi, S., Holland, C. P., \& Papamichail, K. N. (2018). The impact of consumer archetypes on online purchase decision-making processes and outcomes: A behavioural process perspective. Journal of Business Research, 91(May 2017), 71-82. https://doi.org/10.1016/j.jbusres.2018.05.038

Karwur, E. (2016). Pengaruh Retail Marketing Mix Terhadap Keputusan Pembelian di Indomaret Piniki. Jurnal Berkala Ilmiah Efisiensi, 16(03), 196-206.

Kasman, A. M., Maupa, H., \& Jusni, J. (2019). Bauran Pemasaran, Persaingan Pasar dan Kualitas Layanan Terhadap Pilihan Minimarket Sebagai Tempat Berbelanja di Sulawesi Selatan. Jurnal Bisnis, Manajemen 
Jurnal Bisnis dan Manajemen, Volume 21, No. 1, March 2020, p. 27-42

Dan Informatika, 16(1), 55-63.

Kotler \& Keller. (2009). Manajemen Pemasaran. Jilid I. Edisi ke 13. Jakarta: Erlangga.

Kussudyarsana, K. (2008). Budaya Dan Pemasaran Dalam: Tinjauan Pengaruh Budaya Terhadap Perilaku Konsumen. BENEFIT: Jurnal Manajemen Dan Bisnis, 12(2), 172-180.

Kusumowidagdo, A., Sachari, A., \& Widodo, P. (2012). The Impact of Atmospheric Stimuli of Stores on Human Behavior. Procedia Social and Behavioral Sciences, 35(December 2011), 564-571. https://doi.org/10.1016/j.sbspro.2012.02.123

Lestari, M., \& Suhadak. (2019). Pengaruh Pembangunan Infrastruktur Terhadap Pertumbuhan Ekonomi dan Pemerataan Ekonomi Indonesia (Studi Pada Badan Pusat Statistik Tahun 2003-2017). Jurnal Administrasi Bisnis, 70(1), 98-105. Retrieved from administrasibisnis.studentjournal.ub.ac.id $\% 0$ A101

Lupiyoadi, R., \& Hamdani, A. (2008). Bauran Pemasaram Barang vs Jasa. Jakarta: Salemba Empat.

Marendra, I. G. (2018). Pengaruh Bauran Pemasaran (Produk, Harga, Lokasi Dan Promosi) Terhadap Keputusan Pembelian Konsumen Di Minimarket (Alfamart Atau Indomaret). Jurnal Pemasaran Kompetitif, 1(3), 34-52.

Maulana, R., \& Bowo, P. A. (2013). Pengaruh Pertumbuhan Ekonomi, Pendidikan dan Teknologi Terhadap IPM Provinsi di Indonesia 2007-2011. Journal of Economics and Policy, 6(2), 103-213. https://doi.org/10.15294/jejak.v7i1.3596

Mauna, Z., Hufron, M., \& Khoirul, M. A. (2017). Pengaruh Bauran Promosi Terhadap Perilaku Pembelian Secara Implusif Pada Produk Beng-Beng (Studi Kasus Pada Mahasiswa Fakultas Ekonomi UNISMA). Warta Ekonomi, 07(17), 132-146.

Morrison, A.M. (2010). Hospitality \& Travel Marketing. USA: Delmar Cengange Learning.

Nasikan, \& Sasmito, B. A. (2013). Faktor Internal Dan Eksternal Terhadap Keputusan
Pembelian Telepon Selular Merk Nokia. Jurnal Manajemen Dan Akuntansi, 2(1), 85100.

Naufal, A. R., \& Magnadi, R. H. (2017). Pengaruh Promosi, Harga, dan Kualitas Pelayanan Terhadap Keputusan Pembelian (Studi Pada Rahma Rahmi Collection). Diponegoro Journal of Management, 6(4), 1-9. Retrieved from https://ejournal3.undip.ac.id/index.php/djom/ article/view/17954

Oghazi, P., Karlsson, S., Hellström, D., \& Hjort, K. (2018). Online purchase return policy leniency and purchase decision: Mediating role of consumer trust. Journal of Retailing and Consumer Services, 41(September 2017), 190-200. https://doi.org/10.1016/j.jretconser.2017.12.0 07

Parsons, A. G., \& Descatoires, E. (2016). Retail marketing: A novel research agenda. Australasian Marketing Journal, 24(2), 102107.

https://doi.org/10.1016/j.ausmj.2016.05.005

Pertiwi, M. I., Yulianto, E., \& Sunarti, S. (2016). Pengaruh Bauran Pemasaran terhadap keputusan Pembelian (Survei pada Konsumen Baker's King Donuts \& Coffee di MX Mall Malang). Jurnal Administrasi Bisnis, 37(1), 179-186.

Porter, M.E. (2008). Strategi Bersaing (Competitive strategy). Tanggerang: Karisma publishing group.

Rinaldi, M., Jamal, A., \& Seftarita, C. (2017). Analisis Pengaruh Perdagangan Internasional Dan Variabel Makro Ekonomi Terhadap Pertumbuhan Ekonomi Indonesia. Jurnal Ekonomi Dan Kebijakan Publik Indonesia, 4(1), 49-62.

Rochaida, E. (2016). Dampak Pertumbuhan Penduduk Terhadap Pertumbuhan Ekonomi dan Keluarga Sejahtera di Provinsi Kalimantan Timur. Forum Ekonomi, 18(1), 14-24. Retrieved from http://journal.feb.unmul.ac.id/index.php/FOR UMEKONOMI/article/download/42/40

Rosyad, U. N. (2011). Pengaruh Komunikasi Pemasaran Terhadap Perluasan Pangsa Pasar. Mimbar, XXVII(2), 213-224.

Rusdianto, R. (2015). Pengaruh Kinerja Bauran 
Pemasaran dan Kualitas Jasa Terhadap Loyalitas Pasien dan Citra Institusional Serta Implikasinya pada Kineja Rumah Sakit (Suatu Survey Pada Rumah Sakit Kepolisian (Bhayangkara ) di Indonesia). Jurnal Bisnis \& Manajemen, XVI(2), 118-128.

Salim, A. (2002). Perubahan sosial. Yogyakarta: PT Tiara Wacana Yogya.

Sandy, F., Arifin, Z., \& Yaningwati, F. (2014). Pengaruh Bauran Promosi Terhadap Keputusan Pembelian (Survei Pada Mahasiswa Jurusan Bisnis Angkatan 20102012 Fakultas Ilmu Administrasi Pengguna Indosat di Universitas Brawijaya). Jurnal Administrasi Bisnis, 9(2), 1-10.

Schiffman., \& Kanuk. (2004). Perilaku Konsumen. Edisi 7. Jakarta: Prentice Hall.

Sedyaningrum, M., Suhadak, \& Nuzula, N. F. (2016). Pengaruh Jumlah Nilai Ekspor, Impor Dan Pertumbuhan Ekonomi Terhadap Nilai Tukar Dan Daya Beli Masyarakat Di Indonesia (Studi Pada Bank Indonesia Periode Tahun 2006:IV-2015:III). Jurnal Administrasi Bisnis, 34(1), 114-121. Retrieved from http://administrasibisnis.studentjournal.ub.ac. $\mathrm{id} /$ index.php/jab/article/download/1324/1709

Simbolon, F. (2011). Pengaruh Bauran Ritel terhadap Keputusan Pembelian Konsumen pada Departemen Store X di DKI Jakarta. Binus Business Review, 2(1), 88-99. https://doi.org/10.21512/bbr.v2i1.1113

Suki, N. M., Suki, N. M., \& Azman, N. S. (2016). Impacts of Corporate Social Responsibility on the Links Between Green Marketing Awareness and Consumer Purchase Intentions. Procedia Economics and Finance, 37(16), 262-268. https://doi.org/10.1016/s2212-

5671(16)30123-x

Suliyanto. (2006). Metode Riset Bisnis. Yogyakarta: Penerbit Andi.

Tanner, D., \& Tanner, L. (1980). Curriculum Development: Theory into Practice. New York: Macmillan Publishing Co.,Inc.

Tumbel, A. L., \& Rate, P. Van. (2015). Pengaruh Bauran Pemasaran terhadap Keputusan Pembelian di Pasar Tradisional (Studi Pada Pasar Tradisional di Kota Manado). Jurnal LPPM Bidang EkoSosBudKum, 2(2), 60-72.
Wahab, N. A., Hassan, L. F. A., Shahid, S. A. M., \& Maon, S. N. (2016). The Relationship Between Marketing Mix And Customer Loyalty In Hijab Industry: The Mediating Effect Of Customer Satisfaction. Procedia Economics and Finance, 37(16), 366-371. https://doi.org/10.1016/s22125671(16)30138-1

Wandebori, H., \& Wijaya, V. (2017). Consumers' Purchase Intention: Influencing Factors Unveiled at Korean Thematic Café (Case Study: Chingu Café). Trikonomika, 16(1), 28. https://doi.org/10.23969/trikonomika.v16i1.4 25

Wardana, D. P. (2016). Pengaruh Pembangunan Ekonomi Terhadap Pembangunan Manusia Di Kalimantan Timur. INOVASI: Jurnal Ekonomi Keuangan, Dan Manajemen, 12(2), 179-191. Retrieved from http://journal.feb.unmul.ac.id/index.php/INO VASI/article/view/804

Wardhana, A., Syahputra, S., \& Kartawinata, B. R. (2017). Determinant Factors of Consumer Preferences in Indonesia Airlines Industry. Jurnal Bisnis \& Manajemen, XVIII(1), 11$20 . \quad$ Retrieved from https://www.tiket2.com/airlines,

Wardi, Y., Abror, A., \& Trinanda, O. (2018). The Marketing of Higher Education: Managing Student Loyalty Based on Tuition Fee Policy and Service Quality. Jurnal Bisnis Dan Manajemen, 19(2), 101-108. https://doi.org/10.24198/jbm.v19i2.195

Wongleedee, K. (2015). Marketing Mix and Purchasing Behavior for Community Products at Traditional Markets. Procedia Social and Behavioral Sciences, 197(February), 2080-2085. https://doi.org/10.1016/j.sbspro.2015.07.323

Yustika, A.E. (2007). Perekonomian Indonesia: Satu Dekade Pasca Krisis Ekonomi. Malang: BPFE Unibraw.

Yusuf, W. (2007). Membedah Konsep dan Aplikasi CSR (Corporate Social Responsibility). Gresik: Fascho Publishing. 